\title{
Effects of Chicken Manure on Growth and Yield of Jute Mallow (Corchorus olitorius L.) under Rain-Fed Conditions of Sudan
}

\author{
Atif H. Naim1*, Kwthar Mubark Ahmed1, Faisal E. Ahmed ${ }^{2}$ \\ ${ }^{1}$ Department of Crop Sciences, Faculty of Agricultural and Environmental Sciences, University of Gadarif, \\ Gadrif, Sudan \\ ${ }^{2}$ Department of Agronomy, Faculty of Agriculture, University of Khartoum, Khartoum, Sudan \\ Email: atif882002@yahoo.com, fgahmed2005@yahoo.com
}

Received 2 October 2015; accepted 20 October 2015; published 28 October 2015

Copyright (C) 2015 by authors and OALib.

This work is licensed under the Creative Commons Attribution International License (CC BY).

http://creativecommons.org/licenses/by/4.0/

(c) (i) Open Access

\begin{abstract}
A field experiment was conducted in 2013 and 2014 cropping seasons at the Research and Teaching Farms of the Faculty of Agricultural and Environmental Sciences, University of Gadarif, to evaluate the effect of different rates of chicken manure on the growth and yield of jute mallow. The experiment consisted of four levels of chicken manure viz; $0,5,10$, and 20 t/ha. The treatments were arranged in a randomized complete block design with three replicates. The results showed that increasing chicken manure significantly increased all the growth attributes of jute mall and resulted in an increase in crop yield and yield components in both seasons. The present study revealed that jute mallow has a positive response to chicken manure application which succeeded to compensate the deficiency of minerals in the Gadarif State of Sudan under rain-fed conditions. The study also recommend that the highest chicken manure application rate $(20 \mathrm{t} / \mathrm{ha})$ is indispensible for vigorous growth and substantial increase in jute mallow under harsh semi-arid conditions of Sudan.
\end{abstract}

\section{Keywords}

Chicken Manure Fertilizer, Corchorus olitorius, Jute Mallow, Wild Vegetable, Organic Fertilizer

Subject Areas: Agricultural Science

\section{Introduction}

Jute mallow (Corchorus olitorius L.) is an indigenous wild vegetable in Sudan. It belongs to the Family Tiliaceae.

\footnotetext{
"Corresponding author.
}

How to cite this paper: Naim, A.H., Ahmed, K.M. and Ahmed, F.E. (2015) Effects of Chicken Manure on Growth and Yield of Jute Mallow (Corchorus olitorius L.) under Rain-Fed Conditions of Sudan. Open Access Library Journal, 2: e2042. 
The plant is widely spread all over the tropics and it probably exists in all countries of tropical Africa [1]. It is consumed as spontaneous vegetable in fallow land by rural communities in most parts of Africa [2] [3]. It has been documented that jute mallow plays a significant role in the treatment of gonorrhoea, chronic cystitis, pain, fever and tumors [4]. C. olitorius is known to contain high levels of iron and folate which are useful for the prevention of anaemia [5]. The plant leaves are eaten cooked, young leaves and immature fruits are added to salads [2]. The leaves are high in protein and the dried leaves can be used as a thickener in soups [2] [3].

Indigenous vegetables are important in human diet especially for poor communities. They supply the body with essential minerals, vitamins and certain hormone precursors in addition to protein and carbohydrates [6] [7]. Many of these vegetables are more nutritious than exotic vegetables such as cabbage (Brassica oleraceae) and spinach (Spinaceae oleracaea) [8]. Ecologically indigenous vegetables grow more easily in rural subsistence farming systems when compared with exotic vegetable species [9] [10]. This makes indigenous vegetables very important to local resource poor communities of Sudan and other African countries in combating hunger and malnutrition [11] and in fighting against modern age diseases such as cancer [4] and HIV and AIDS [3].

Low soil fertility is considered as one of the main factors responsible for the low productivity of vegetables [12]. According to a report by the Food and Agriculture Organization (FAO) of the United Nations [13] the prospects of obtaining adequate chemical fertilizers to meet the requirement of the teeming farming population are remote in many developing countries. The report further stated that the prevailing exorbitant prices of mineral fertilizers and shortage in their supplies have shifted the attention of many farmers towards making better use of organic manure as an alternative source of plant nutrients. Animal manure has been used for plant production effectively for centuries. Among the different sources of these manure, chicken manure was found to be the most concentrated in terms of nutrient content [14].

The increasing demand for chicken meat in Sudan has prompted more chicken farming with consequent effects on increasing utilization of chicken manure as fertilizers. Some researchers [15] observed that application of chicken manure improved the availability of some minerals in the soil, and especially the transfer of nutrients from rangeland to the crop plant. Recently, a scientist [16] reported that chicken manure, especially those produced in deep litter or battery cage house are the richest known farmyard manure supplying greater amounts of absorbable plant nutrient. In their recent work some researchers [17] reported that chicken manure increased the leaf area, total chlorophyll content and grain yield of maize and sorghum. According to [18], chicken manure mineralizes faster than other animal manure such as cattle or pig dung; hence it releases its nutrients for plant uptake and utilization rapidly. In an old literature; for example [19], it was reported that chicken manure contains basic nutrients required for enhancing growth and yield of crops. Application of chicken manure increases carbon content, water holding capacity, aggregation of soil, and decreases bulk density [20]. It also increases the water soluble and exchangeable potassium and magnesium which enhance crop yield [21].

At present, there are no recommended standards with respect to rate of chicken manure or other soil amendment material for enhancement of vegetables yield in the Sudan. Therefore, the objective of this study therefore, was to identify the most appropriate rate of application of chicken manure for growth and yield of jute mallow under rain-fed conditions in Gadarif State, Sudan.

\section{Materials and Methods}

\subsection{Description of the Experimental Site}

A Field experiment was conducted at the Research and Teaching Farms of the Faculty of Agricultural and Environmental Sciences, University of Gadarif. The experimental site is located within latitude $14^{\circ} 02^{\prime} \mathrm{N}$ of the Equator and longitude $35^{\circ} 28^{\prime} \mathrm{E}$ of Greenwich. Its average altitude is $600 \mathrm{~m}$ a.s.l. The experiment was conducted during the 2013 and 2014 cropping seasons in semi-arid climatic conditions with an aridity index ranging from 0.2 to 0.4 [22]. The annual rainfall is less than $500 \mathrm{~mm}$ in the northern part of Gadarif State; however, the rainfall is erratic and concentrated in only few months of the year mainly from May to October. According to [23], the average temperature of this region varies between a mean minimum of $22^{\circ} \mathrm{C}$ in winter and a mean maximum of $37^{\circ} \mathrm{C}$ in summer. The study area receives the highest temperature between April and May. During such times, the hottest day can go up to $40^{\circ} \mathrm{C}-42^{\circ} \mathrm{C}$ [23]. The most prominent types of the soil in the studied area are heavy dark cracking clays in which the clay content is very high, amounting 70 to 80 per cent [24]. Monmorillonite is the common clay type in the area, and its content varies between 47 and 75 per cent. Cracks can be 3 to $10 \mathrm{~cm}$ wide and can be as deep as $2 \mathrm{~m}$ during the dry season. Cation exchange capacity ranges from 50 to $100 \mathrm{mg} 100$ 
$\mathrm{g}^{-1}$ with calcium constituting more than half of the exchangeable cations [24]. Soil $\mathrm{pH}$ is near neutrality in general with 1 to 3 per cent free carbonates. Nitrogen content is low and ranges from $0 \cdot 05$ to $0 \cdot 15$ per cent [24]. Generally, the soils have low to moderate amounts of phosphorous content [24]. The concentration of potassium ranges from 400 to $600 \mathrm{ppm}$, which is considered as an adequate amount [24] [25]. Land use system in the area is dominated by agricultural activities such as sorghum and sesame cultivation, livestock rearing and forestation [24].

\subsection{Land Preparation}

The experimental site was disc ploughed, disc harrowed to crush clods and levelled out to maintain a well levelled seed bed and then followed by ridging up to $0.7 \mathrm{~m}$ between ridges which were oriented in a north-south direction. Individual plot size was $4 \times 5$ meters consisting of 6 ridges of 4 meters in length. In each plot, 2nd and 5th ridges were used for sampling. Plot sizes of $2.6 \times 2.25 \mathrm{~m}^{2}$ were made and composite samples collected from the plots at $0-15 \mathrm{~cm}$ depth in order to assess the initial physical and chemical properties of the soils.

\subsection{Laboratory Studies}

The composite soil samples collected from the individual plots were air-dried in a room temperature of $27^{\circ} \mathrm{C}$ for three days, crushed and sieved using $2 \mathrm{~mm}$ aperture. The parameters evaluated include the particle size distribution by hydrometer method [26]. The $\mathrm{pH}$ was determined using Pye Unican model MK2 $\mathrm{pH}$ meter in a 1:2.5 soil/water suspension ratio. Organic carbon was determined by Walkley-Black wet oxidation method [27]. Total nitrogen was determined by micro-Kjeldahl distillation technique as described by [28]. Available phosphorus was determined by Bray No. 1 method [29]. Exchangeable potassium was determined by flame photometer, while cation exchange capacity (CEC) was determined by Ammonium acetate saturation method [30]. The chemical analysis of the chicken manure used for the experiment was also evaluated using appropriate methods as described in the IITA (International Institute for Tropical Agriculture) manuals [29].

\subsection{Treatments and Design}

The experiment was carried out in a Randomized Complete Block Design (RCBD) with three replicates. Rates of chicken manure in tons per hectare were $0,5,10$, and 20.

\subsection{Cultural Practices}

\subsubsection{Fertilization}

The type of manure used was chicken manure, which was collected from a poultry farm in Gadarif. The fertilizer was applied on 15/7/2013 in the first season and on 18/7/2014 in the second season. The organic fertilizer was broadcasted manually on the bottom of the ridges mixed with soil and distributed equally to the entire plot using a hand hoe and then irrigated immediately.

\subsubsection{Sowing Date and Seeding Rate}

Sowing was done manually on one side of the ridge (eastern side of ridge) and it was carried out on August, 10th. The seed rate applied was $12 \mathrm{Kg} / \mathrm{fed}$.

\subsubsection{Weeding}

Weeding was practiced twice during the growing period 21 and 35 days from sowing.

\subsection{Growth and Yield Parameters}

For Growth parameters measurements and number of pods per plant at harvesting, five plants were randomly selected from the 2nd and 5th ridges of each individual plot, and the plants were tagged during the study period as follows:

1) Plant height $(\mathrm{cm})$ : The height of the plant was measured using a meter ruler from the plant base to the terminal bud. The five tagged plants from each plot were measured and the mean height was taken to represent each replicate plant height which measured after 4, 6 and 8 weeks from sowing. 
2) Number of leaves per plant: This parameter was measured after 4, 6 and 8 weeks from sowing by calculating all leaves of the five randomly selected plants. The mean number of leaves per plant was recorded.

3) Leaf area $\left(\mathrm{cm}^{2}\right)$ : The leaf area was measured after 4, 6 and 8 weeks from sowing. Fully expanded leaves were randomly sampled from each plot and the area was measured by tracing each leaf on a graph paper with grid squares, each measuring $1 \mathrm{~cm}$ by $1 \mathrm{~cm}$. The mean was taken to represent each replicate.

4) Stem diameter (mm): Measured at harvest by using a vernier (caliper) from the middle of the 2nd internode of five plants then the mean stem diameter were calculated.

5) Plant and pod mass fresh and dry weight (g): At maturity phase of all plants both fresh and dry matter were measured for the shoots (stem and leaves) and pods. For the shoots, all plants in each plot were harvested and put together in a brown weighing paper bags as per each treatment. The average was taken for each replicate. Similarly, the pods were harvested and placed in sampling bags. The fresh samples were taken to the laboratory to measure the fresh weight using an electronic balance (PGW 4502e), max: $4500 \mathrm{~g}$ and readability: $0.01 \mathrm{~g}$. The same samples were then oven dried to constant weight at $80^{\circ} \mathrm{C}$ using a hot air oven (Scientific Series 2000) and dry weight was recorded.

6) Number of pods/plant: At harvesting, the number of pods in each one of the tagged plants were counted and then the average was calculated for each replicate to represent the mean number of pods in each replicate for all treatments of the present study.

\section{Results and Discussion}

\subsection{Plant Height}

The present study revealed that fertilization with chicken manure treatments significantly $(\mathrm{p}<0.01)$ increased jute mallow plant height compared with control treatment (Figure 1(a) \& Figure 1(b)) in both seasons 2013 and 2014. The plants that received $20 \mathrm{t} / \mathrm{ha}$ of chicken manure had the highest height while plants in the control which were grown without chicken manure had the lowest plant height at all growth occasions. This is in harmony with the findings and reports of many researchers [14]-[16] [31]. It is also similar to the findings of [32] who reported increased plant height of pepper resulting from application of high rate of chicken manure.

\subsection{Number of Leaves/Plant}

The average number of leaves per plant was significantly $(\mathrm{P}<0.05)$ different across all treatments. The highest number of leaves was obtained from jute mallow provided with 20 t/ha chicken manure (Figure 2(a) and Figure 2(b)) at both seasons 2013 and 2014. Number of leaves decreased significantly $(P<0.05)$ with each decrease in level of chicken manure applied. The lowest number of leaves was obtained from jute mallow plants which did not receive chicken manure fertilizer. It is also similar to the findings of [32] who reported increased number of leaves of pepper resulting from application of high rate of chicken manure. This could be attributed to the fact that $20 \mathrm{t} / \mathrm{ha}$ was compatible with the requirements and growing characteristics of the crop, drainage and slope of the land. This is in consonance with the findings of [8] [33] who recommended that manure be applied at rates that are compatible with the nutrient requirements and growing characteristics of the crops for growth and yield enhancement.

\subsection{Leaf Area $\left(\mathrm{cm}^{2}\right)$}

The response of leaf area of jute mallow to rates of chicken manure in 2013 and 2014 is shown in Figure 3(a) \& Figure 3(b). There were significant differences in leaf area of the plants in both years of evaluation. During both seasons, the mean of leaf area of plants that received $20 \mathrm{t} / \mathrm{ha}$ was the highest, while plants that received $\mathrm{O} t / \mathrm{ha}$ (the control treatment) of chicken manure had the lowest mean leaf area. Chicken manure application rate of 20 t/ha increased leaf area more than the other application rates possibly because an increase in chicken manure was suitable for increasing carbon content, water holding capacity, aggregation of soil and decrease of bulk density, all of which interplay to increase leaf area and total chlorophyll content of wild okra. This is consistent with the findings of [17] [19] [20] who reported that increased application rate of chicken manure enhanced lead area, total chlorophyll content, carbon content, water holding capacity, and decrease bulk density of soil which culminate and interplay to promote crop yield. 

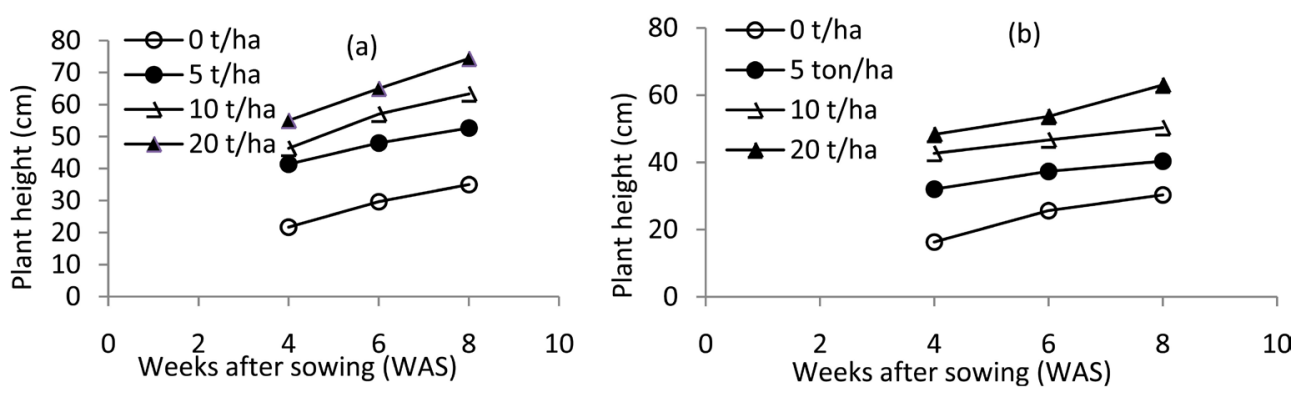

Figure 1. Effect of various levels of chicken manure fertilizer on jute mallow (Corchorus olitorius) Plant height (cm) during season 2013 (a) and season 2014 (b).
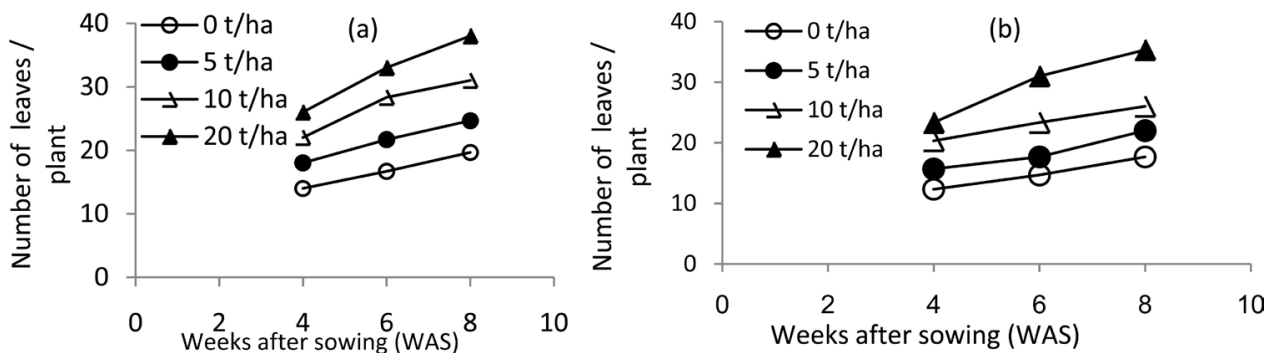

Figure 2. Effect of various levels of chicken manure fertilizer on jute mallow (Corchorus olitorius) number of leaves/plant during season 2013 (a) and 2014 (b).
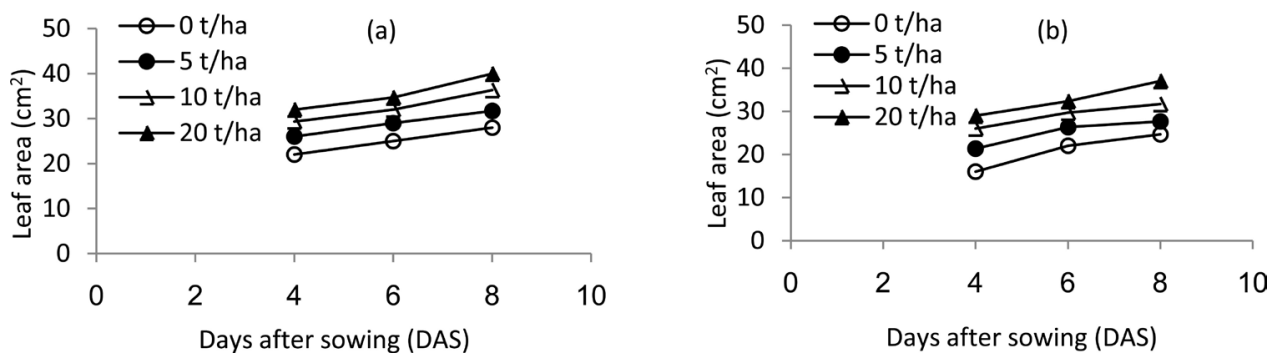

Figure 3. Effect of various levels of chicken manure fertilizer on jute mallow (Corchorus olitorius) leaf area during ( $\mathrm{cm}^{2}$ ) season 2013 (a) and 2014 (b).

\subsection{Stem Diameter ( $\mathrm{mm})$}

In comparison among the treatments, the effect of the treatments on stem diameter of $C$. olitorius was highly significant ( $<0.01$ ) among all treatments studied (Table 1). Fertilization treatments with chicken manure significantly increased stem diameter of jute mallow compared with the control treatment. Among chicken manure application rates, the plant received $20 \mathrm{t} / \mathrm{ha}$ scored the highest mean stem diameter for both seasons $(7.65 \mathrm{~mm})$. Increasing chicken manure rates resulted in a significant increase in stem diameter in both years of evaluation. Plants that did not received chicken manure (the control) scored the lowest mean stem diameter for both seasons (3.65). The decrease observed in stem diameter for plants that did not received chicken manure could be attributed to depletion of soil nutrients as a result of leaching reported by [34] and loss of soil nutrients as a result of continuous cropping at Gadarif State. Similar results were reported by some researchers [35] [36]. According to [36] chicken manure is rich in nitrogen and since nitrogen enhances plant growth in general, this increase in stem diameter due high application rate of chicken manure fertilization is expected.

\subsection{Plant Mass Fresh and Dry Weight (g)}

Plant Fresh and dry weight were highly significant at $(\mathrm{p}<0.01)$ (Table 1).The three chicken manure treatments ( $5 \mathrm{t} / \mathrm{ha}, 10 \mathrm{t} / \mathrm{ha}$ and $20 \mathrm{t} / \mathrm{ha}$ ) had high values in both fresh and dry weight compared with the control (Table 2). This could have been caused by the increment of mineral content as the manure decomposed and released certain 
Table 1. Effect of various levels of chicken manure fertilizer on jute mallow (Corchorus olitorius), stem diameter, plant mass fresh and dry weight during season 2013 and season 2014.

\begin{tabular}{|c|c|c|c|c|c|c|}
\hline \multirow{2}{*}{ Chicken manure rate } & \multicolumn{2}{|c|}{ Stem diameter (mm) } & \multicolumn{2}{|c|}{ Plant mass fresh weight (g) } & \multicolumn{2}{|c|}{ Plant mass dry weight (g) } \\
\hline & 2013 & 2014 & 2013 & 2014 & 2013 & 2014 \\
\hline $0 \mathrm{t} / \mathrm{ha}$ & 3.3 & 4.0 & 15.7 & 17.7 & 3.3 & 6.0 \\
\hline $5 \mathrm{t} / \mathrm{ha}$ & 6.0 & 6.0 & 21.0 & 24.3 & 5.7 & 10.3 \\
\hline $10 \mathrm{t} / \mathrm{ha}$ & 7.0 & 7.3 & 33.3 & 34.0 & 6.3 & 15.3 \\
\hline $20 \mathrm{t} / \mathrm{ha}$ & 8.0 & 7.3 & 38.3 & 40.3 & 9.0 & 20.0 \\
\hline Significance & * & * & $* * *$ & $* * *$ & ** & * \\
\hline $\mathrm{LSD}_{0.05}$ & 2.71 & 2.24 & 4.98 & 3.65 & 2.66 & 2.76 \\
\hline C.V (\%) & 19.29 & 18.21 & 6.66 & 5.43 & 18.66 & 16.34 \\
\hline
\end{tabular}

Table 2. Effect of various levels of chicken manure fertilizer on Jute mallow (Corchorus olitorius) number of pods/plant , pod fresh and dry weight during season 2013 and 2014.

\begin{tabular}{|c|c|c|c|c|c|c|}
\hline \multirow{2}{*}{ Chicken manure rate } & \multicolumn{2}{|c|}{ Number of pods/plant } & \multicolumn{2}{|c|}{ pod fresh weight (g) } & \multicolumn{2}{|c|}{ pod dry weight (g) } \\
\hline & 2013 & 2014 & 2013 & 2014 & 2013 & 2014 \\
\hline $0 \mathrm{t} / \mathrm{ha}$ & 15.0 & 18.0 & 6.0 & 6.0 & 1.5 & 1.8 \\
\hline $5 \mathrm{t} / \mathrm{ha}$ & 21.7 & 24.0 & 10.33 & 10.3 & 2.1 & 2.7 \\
\hline $10 \mathrm{t} / \mathrm{ha}$ & 25.7 & 31.0 & 15.33 & 15.3 & 3.5 & 4.0 \\
\hline $20 \mathrm{t} / \mathrm{ha}$ & 31.7 & 37.0 & 20.0 & 20.0 & 4.6 & 5.1 \\
\hline Sign. & $* * *$ & $* * *$ & $* * *$ & $* * *$ & $* * *$ & $* * *$ \\
\hline LSD0.05 & 4.1 & 4.6 & 2.9 & 2.6 & 0.46 & 0.66 \\
\hline C.V (\%) & 8.91 & 8.9 & 12.0 & 12.3 & 10.3 & 9.7 \\
\hline
\end{tabular}

minerals in the respective treatments. According to [37], plant biomass production and numbers of leaves are highly correlated, that is, the plants with more leaves produce high plant biomass because of highly photosynthetic rate. This was the case (in the present study) with the high values of leaf number recorded in favor of the highest rate of chicken manure treatment (Figure 2(a) and Figure 2(b)). The results of this study are in accord with the results of another study conducted by [3] who found that different levels of chicken manure applications behaved differently in terms of harvest parameters as was shown by the significant $(p<0.05)$ differences in dry matter. The highest dry matter was obtained from lettuce supplied with $60 \mathrm{t} / \mathrm{ha}$ chicken manure. Dry matter decreased with each decrease in level of chicken manure application rate.

\subsection{Yield Parameters}

In Table 2, the maximum number of pods and pod fresh and dry weight per plant was recorded for plants received chicken manure whereas control treatment gave the lowest number and fresh and dry mass of pods per plant. Marketable yield of jute mallow was significantly increased with the increment levels of chicken manure. This might be attributed to the stimulating effect of chicken manure that supplies plant with nutrients required for better yield [38]. For application of chicken manure at different levels, the highest rates of chicken manure (10 and $20 \mathrm{t} / \mathrm{ha}$ ) gave a significantly substantial high yield of pods and yield fresh and dry weight than other rates. These results are in good agreement with the findings of several researchers who revealed that organic manure increases the vegetative growth and biomass production effectively [39]-[41]. Moreover, some researchers [42]-[45] emphasized that the increment of application of organic manure increases the growth, dry matter accumulation, yield and quality of the plant.

\section{Conclusion}

From the results of present investigation, on the basis of plant growth and dry weight yield it may be concluded that chicken manure produced significantly higher plant height, stem and leaf dry weight, leaf area index, total 
dry weight and dry weight yield compared with the control. Increasing the rate of applied manure from 5 ton/ha to 20 ton/ha significantly increased all the growth and yield attributes measured. However, application of 20 ton/ha of chicken manure produced the highest growth and yield and is therefore recommended.

\section{Acknowledgements}

The authors would like to thank University of Gadarif for financial support. Additionally, the authors are grateful to laboratory staffs of the National Centre of Research for their kind assistance in chemical analysis of chicken manure.

\section{References}

[1] PROTA (2010) "Plant Resources of Tropical Africa” PROTA4U Record Display. http://database.prota.org/PROTAhtml/Corchorus\%20olitorius_En.htm

[2] Hedrick, U.P. (2010) Sturvant's Edible Plants of the World. Plants for the Future. http://www.swsbm.com/Ephemera/Sturtevants_Edible_Plants.pdf

[3] Masarirambi, M.T., Sibandze, N., Wahome, P.K. and Oseni, T.O. (2010) Effect of Kraal Manure Application Rates on Growth and Yield of Wild Okra (Corchorus olitorius L.) in Sub-Tropical Environment. Asian Journal of Agricultural Sciences, 4, 89-95. http://www.researchgate.net/profile/Tajudeen_Oseni/publication/264885014

[4] Zakaria, Z.A., Somchit, M.N., Zaiton, H.A., Mat Jais, M. and Sulaiman, M.R. (2006) The in Vitro Antibacterial Activity of Corchorus olitorius Extracts. International Journal of Pharmacology, 2, 213-215. http://dx.doi.org/10.3923/ijp.2006.213.215

[5] Oyedele, D.J., Asonugho, C. and Awotoye, O.O. (2006) Heavy Metals in Soil and Accumulation by Edible Vegetables after Phosphate Fertilizer Application. Electronic Journal of Agriculture and Food Chemistry, 5, 1446-1453. http://www.researchgate.net/profile/Olusegun_Awotoye/publication/265872785_ISSN_1579-4377

[6] Ekesa, B.N., Walingo, M.K. and Abukutsa-Onyango, M.O. (2009) Accessibility to and Consumption of Indigenous Vegetables and Fruits by Rural Households in Central Africa. African Journal of Food, Agriculture, Nutrition and Development, 85, 90-101. http://www.ajol.info/index.php/ajfand/article/view/48410

[7] Kader, A., Penelope, P. and Gene, E. (2006) Nutritional Quality of Fruits, Nuts and Vegetables and Their Importance in Human Nutrition, Department of Pomology, University of California Subtropical Agricultural Research Centre, USDA/ARS

http://www.researchgate.net/publication/237425054_Nutritional_Quality_of_Fruits_Nuts_and_Vegetables_and_their_I mportance_in_Human_Health

[8] Ndlovu, J. and Afolayan, A.J. (2008) Nutritional Analysis of the South African Wild Vegetable (Corchorus olitorius L.). Asian Journal of Plant Science, 7, 615-618. http://dx.doi.org/10.3923/ajps.2008.615.618

[9] Modi, M., A.T. Modi, S. Hendricks, A. (2006) Potential Role for Wild Vegetables in Household Food Security: A Preliminary Case Study in Kwazulu-Natal, South Africa. African Journal of Food, Agriculture, Nutrition and Development, 6, 1-13. http://www.ajfand.net/Volume6/No1/Modi1850.pdf

[10] Schippers, R.R. (2000) African Indigenous Vegetables: An Overview of the Cultivated Species. Natural Resource Institute/ACP-EU. Technical Centre for Agricultural and Rural Cooperation, Chatham, UK.

[11] Jansen Van Rensburg, W.S., Ventel, S.L., Netshiluvhi, T.R., Van Den Heever, E., Voster, H.J. and De Ronde, J.A. (2004) The Role of Indigenous Leafy Vegetables in Combating Hunger and Malnutrition. South African Journal of Botany, 70, 52-59. http://dx.doi.org/10.1016/S0254-6299(15)30268-4

[12] Hamden, M.I.K. and Fadni, O.E. (2010) Effect of Different Types of Organic Fertilizers on Growth, Quality and Yield of Tomatoes in Sandy Soil. Agriculture Research Corporation. 2nd Ruforum Biennial Meeting, Entebbe, 20-24 September 2010.

[13] Food and Agriculture Organization (1975) Organic Materials as Fertilizers. FAO Soils, Bulletin No. 27. FAO United Nations, Rome, 394 p.

[14] Lombin, L.G., Adepetu, J.A. and Ayolade, K.A. (1992) Complementary Use of Organic Manure and Inorganic Fertilizer in Arable Crop Production. In: Lombin, L.G., Adepetu, J.A. and Ayolade, K.A., Eds., Organic Fertiliser in the Nigeria Agriculture: Present and Future, Proceedings of National Organic Fertilizer Seminar, Zaria, Federal Ministry of Science and Technology, Abuja, 146-162.

[15] Kotschi, J.A., Waters-Bayer, A., Adelhelm, A. and Hoeste, U. (1989) Eco-Farming. Tropical, Agro-Ecology. Magraf Verlag, Weikersheim, 132.

[16] Izunobi, N.D. (2002) Poultry Husbandry: An Integrated Approach for Tertiary Students, Extension Agents, Policy Makers and Farmers. Mgbe-Bpp Publishing House, Ihiala. 
[17] Amujoyegbe, B., Opabode, J.T. and Olayinka, A. (2007) Effect of Organic and Inorganic Fertilizer on Yield and Chlorophyll Content of Maize (Zea mays L.) and Sorghum (Sorghum bicolor L. Moench). African Journal of Biotechnology, 16, 1869-1873. http://www.ajol.info/index.php/ajb/article/view/57814

[18] Brady, C. and Weils, R.R. (1999) Nature and Properties of Soil. 12th Edition, Prentice Hall, New Delhi, 74-114.

[19] Sharpley, A.N. and Smith, B.J. (1991) Nitrogen and Phosphorus Forms in Soils Receiving Manure. Soil Science, 15, 253-258. http://naldc.nal.usda.gov/download/19020/PDF

[20] Egerszegi, E. (1990) Effect of Sewage Sludge and Compost Applied to the Soil on Some Physical and Chemical Properties. Journal of Environmental Quality, 15, 122-127.

[21] Jackson, H. (1999) Land Disposal of Broiler Litter: Changes in Soil Potassium, Calcium and Magnesium. Journal of Environment Quality, 4, 202-206. http://dx.doi.org/10.2134/jeq1975.00472425000400020014x

[22] Elhag, M.M. (2006) Causes and Impacts of Desertification in the Butana Area of Sudan. PhD Thesis, University of the Free State, Bloemfontein. http://etd.uovs.ac.za/ETD-db/theses/available/etd-07302007-140717/unrestricted/ElhagMM.pdf

[23] Hamdoun, M.A., Ageeb, A.O. and Dawelbeit, I.M. (1991) Review on Applied Research Simsim Dry Land Farming. CRC Press, Boca Raton.

[24] Biro, K., Pradhan, B., Buchroithner, M. and Makeschin, F. (2011) Land Use/Land Cover Change Analysis and Its Impact on Soil Properties in the Northern Part of Gadarif Region, Sudan. Land Degradation and Development, 24, 90102. http://onlinelibrary.wiley.com/doi/10.1002/ldr.1116/abstract

[25] SKAP (Southern Kassala Agricultural Project) (1992) Land Use Survey Report (Main Report). Vol. 1, Khartum.

[26] Gee, G.W. and Bauder, J.W. (1986) Particle-Size Analysis. In: Klute, A., Ed., Methods of Soil Analysis, Part 1, 2nd Edition, Agronomy Monograph 9, ASA and SSSA, Madison, 383-411.

[27] Nelson, D.W. and Sommer, L.E. (1982) Total Carbon, Organic Carbon, and Organic Matter. In: Page, A.L. Miller, R.H. and Keeney, D.R., Eds., Methods of Soil Analysis, Part 2, 2nd Edition, ASA Monogragh 9, American Society of Agronomy, Madison, 539-579.

[28] Bremner, J.M. and Mulvaney, C.S. (1982) Nitrogen-Total. In: Page, A.L. Miller, R.H. and Keeney, D.R., Eds., Methods of Soil Analysis, Part 2, 2nd Edition, ASA Monogragh 9, American Society of Agronomy, Madison, 595-624.

[29] IITA (International Institute for Tropical Agriculture) (1979) Laboratory Manual for Soil and Plant Analysis. Manual Series 7, IITA, Ibadan.

[30] Roades, J.D. (1982) Cation Exchange Capacity. In: Page, A.L. Miller, R.H. and Keeney, D.R., Eds., Methods of Soil Analysis, 2nd Edition, ASA Monogragh 9, Part 2, American Society of Agronomy, Madison.

[31] Fabiyi, L.L. and Ogunfowora, O.O. (1992) Economics of Production and Utilization of Organic Fertilizer and Inorganic Fertilizer in the Nigeria Agriculture in Present and Future. Federal Ministry of Science and Technology, Lagos, 138-144.

[32] Fagimi, A.A. and Odebode, C.A. (2007) Effects of Poultry Manure on Pepper Veinal Mottle Virus (PVMV) on Yield and Agronomic Parameters of Pepper (Capsicum annum) in Nigeria. East Africa Journal of Science, 1, 104-111. http://www.ajol.info/index.php/eajsci/article/view/40348

[33] DIPA (2006) Directorate of Information and Publications of Agriculture. Handbook of Agriculture: Facts and Figures for Farmers, Students and All Interested in Farming. Indian Council of Agricultural Research, New Delhi, 435.

[34] Mathowa, T., Chinachit, W., Yangyuen P. and Isarangkool Na Ayutthaya, S. (2012) Changes in Turf Grass Leaf Chlorophyll Content and Some Soil Characteristics as Influenced by Irrigation Treatments. International Journal of Environmental and Rural Development, 3,181-187. http://www.researchgate.net/publication/259099748

[35] Akintoye, M. (1996) Thesis Abstract. International Institute of Tropical Agricultural Research, 25-27.

[36] Hassan, M.E. (2010) Effect of Organic Fertilizer and Urea on Growth, Yield and Quality of Fodder Maize (Zea mays L.). International Journal of Current Research, 8, 35-41.

[37] Johnson, C.D. and Decoteau, D.R. (1996) Nitrogen and Potassium Fertility Affects Jalapeño Pepper Plant Growth, Pod Yield, and Pungency. Horticultural Science, 2, 1119-1123. http://hortsci.ashspublications.org/content/31/7/1119.abstract

[38] Abdelrazzag, A. (2002) Effect of Chicken Manure, Sheep Manure and Inorganic Fertilizer on Yield and Nutrients Uptake by Onion. Pakistan Journal of Biological Sciences, 5, 266-268. http://dx.doi.org/10.3923/pjbs.2002.266.268

[39] Dinesh, R., Srinivasan, V., Hamza, S. and Manjusha, A. (2010) Short-Term Incorporation of Organic Manures and Biofertilizers Influences Biochemical and Microbial Characteristics of Soils under an Annual Crop Turmeric (Curcuma longa). Bioresource Technology, 101, 4697-4702. http://dx.doi.org/10.1016/j.biortech.2010.01.108

[40] Mannikeri, I.M. (2006) Studies on Production Technology of Turmeric (Curcuma longa L.). Doctor of Philosophy Thesis, Department of Horticulture, University of Agricultural Sciences, Dharwad, 1-125. 
[41] Mohapatra, S.C. and Das, T.K. (2009) Integrated Effect of Biofertilizers and Organic Manure on Turmeric (Curcuma longa). Environment and Ecology, 27, 1444-1445.

http://www.cabdirect.org/abstracts/20093339183.html;jsessionid=82398DCE70AB43710552F0727B27E749

[42] Manhas, S.S. and Gill, B.S. (2010) Effect of Planting Materials, Mulch Levels and Farmyard Manure on Growth, Yield and Quality of Turmeric (Curcuma longa L.). The Indian Journal of Agricultural Science, 80, 227-233. http://epubs.icar.org.in/ejournal/index.php/IJAgS/article/view/63

[43] Mishra, S. and Jain, A. (2013) Effect of Integrated Nutrient Management on Andrographolide Content of Andrographis paniculata. Nature and Science, 11, 30-32. http://www.sciencepub.net/nature/ns1108/005_17275ns1108_30_32.pdf

[44] Ramesh, G., Shivanna, M.B. and Santa Ram, A. (2011) Interactive Influence of Organic Manure and Inorganic Fertilizers on Growth and Yield of Andrographis paniculata. International Research Journal of Plant Science, 2, 16-21. http://interesjournals.org/full-articles/-interactive-influence-of-organic-manures-and-inorganic-fertilizers-on-growthand -yield-of-kalmegh-andrographis-paniculatanees.pdf?view=inline

[45] Sanjutha, S., Subramanian, S., Indu Rai, C. and Maheswari, J. (2008) Integrated Nutrient Management of Andrographis paniculata. Research Journal of Agriculture and Biological Science, 4, 141-145. http://www.researchgate.net/profile/Maheswari_Jayakannan/publication/233753282 